\title{
Social inequalities in health among the elderly
}

\author{
Desigualdades sociais em saúde entre idosos
}

\footnotetext{
${ }_{1}^{1}$ Faculdade de Ciências Médicas, Universidade Estadual de Campinas, Campinas, Brasil.

2 Universidade de São Paulo,

São Paulo, Brasil.

Correspondence

M. B. A. Barros

Faculdade de Ciências

Médicas, Universidade

Estadual de Campinas.

Rua Tessália Vieira de

Camargo 126, Campinas, SP

13084-971, Brasil.

marilisa@unicamp.br
}

\begin{abstract}
The aim of the present study was to assess social inequalities in health status, health behavior and the use of health services based on education level. A population-based cross-sectional study was carried out involving 1,518 elderly residents of Campinas, São Paulo State, Brazil. Significant demographic and social differences were found between schooling strata. Elderly individuals with a higher degree of schooling are in greater proportion alcohol drinkers, physically active, have healthier diets and a lower prevalence of hypertension, diabetes, dizziness, headaches, back pain, visual impairment and denture use, and better self-rated health. But, there were no differences in the use of health services in the previous two weeks, in hospitalizations or surgeries in the previous year, nor in medicine intake over the previous three days. Among elderly people with hypertension and diabetes, there were no differences in the regular use of health services and medication. The results demonstrate social inequalities in different health indicators, along with equity in access to some health service components.
\end{abstract}

Health of the Elderly; Morbidity Surveys; Social Inequity; Prevalence
Marilisa Berti de Azevedo Barros 1 Priscila Maria Stolses Bergamo Francisco 1 Margareth Guimarães Lima 1 Chester Luiz Galvão César 2

\section{Introduction}

Studies on social inequalities in health have gained a new emphasis and focus, as methods for measuring disparities have improved and been systematized, health issues that are submitted to analysis have been broadened and studies produced in developed countries have revealed health gaps that encompass the whole society and not only the segment below the poverty line 1,2 . These factors have led multinational agencies and organizations to promote initiatives that incorporate health equity in political agendas and to propose and evaluate strategies for addressing the problem $3,4,5$.

Different concepts and approaches have been applied to health inequality research 2,6. Different strata definitions have been used 7 including concepts of social class ${ }^{8}$. Some studies assessed the impact of the concentration of wealth on health 9 and others analyzed the effect of broader-scoped policies, including the political party in government, on the magnitude of social disparities in health 10 .

According to the literature, the size of social disparities varies with the health problem in question and the demographic subgroups analyzed. Multiple cultural and contextual variables influence the effect of the socioeconomic dimension on health. Social inequality tends to decline with age, being less accentuated among the elderly than in young adults and children 11,12. 
This reduction largely results from the premature death that affects socially underprivileged segments. A study carried out on American population sample revealed that individuals at forty years of age, living below the poverty line, have patterns of biological risk similar to those at sixty years of age with a better socioeconomic status. Moreover, the life expectancy of the former group is 20 years lower than the latter 12. The ageing process itself is more intense among individuals with a poorer socioeconomic status 13 . Despite the reduction in social inequality in health among the elderly, compared to younger people, it tends to persist among the underprivileged stratum as the result of unfavorable conditions throughout life 14 .

The effectiveness of policies and strategies for reducing inequality in health has been demonstrated in a number of studies. A comparison of the distribution of the prevalence of hypertension reveals a social gradient in the United States and an absence of this pattern in Canada, likely to be the result of universal health coverage and policies aimed at socially needier segments in the latter country ${ }^{15}$. Also in Canada, the lowest income segment of a province with anti-poverty social strategies is in a more favorable situation on the prevalence of several chronic diseases than that of a richer province with better mean health indicators, but with no similar policies 16 .

Considering the available literature on health inequalities among the elderly, the aim of the present study was to determine the magnitude of social inequality in health status, health-related behavior and use of health services among elderly individuals, seeking to assess the degree of social disparity in different health dimensions and offer information that may assist in the drafting of interventions.

\section{Methods}

A population-based cross-sectional study was carried out involving 1,518 non-institutionalized individuals aged 60 years or more, who were residents of urban areas in the city of Campinas, São Paulo State, Brazil, between 2008 and 2009, and made up part of the sample of the ISA-Camp $2008 / 2009$ health survey. A previous survey with similar contents and methods was developed in $2001 / 200217$. Campinas is the 14th largest city in Brazil in terms of population (with more than one million inhabitants) and is located $100 \mathrm{~km}$ from the capital city of the state of São Paulo.

The ISA-Camp sample was obtained through a probabilistic stratified cluster sample in two stages. In the first stage, 50 census tracts were selected with a probability proportional to the number of households. The selection was systematic, with the census tracts ordered by the percentage of heads of household with a university education, thereby producing an implicit stratification based on the schooling of the head of the household.

The sample size was obtained considering the estimation of a proportion of 0.50 , with $95 \%$ confidence intervals (95\%CI), a sampling error of $4 \%$ to $5 \%$ and a effect design of 2 , totaling 1,000 individuals in each of the following age groups: adolescent (10 to 19 years), adult (20 to 59 years) and elderly (60 + years). Anticipating an $80 \%$ coverage and response rate, the sample size was corrected to 1,250 . To achieve this sample size in each age group, 2,150, 700 and 3,900 households were independently selected to obtain the expected number of adolescents, adults and elderly individuals, respectively. All residents in the selected age group for the household in question were interviewed. In this study we used only the data involving individuals aged 60 or more.

Information on demographic and socioeconomic variables, illnesses and the use of health services was obtained through a previously tested structured questionnaire administered in home interviews by trained and supervised interviewers.

The variables analyzed in the present study were:

- Schooling (the defining variable of the social segments to be analyzed), assessed in terms of years of study and categorized as: three years or fewer, four to eight years and nine or more years;

- Demographic and socioeconomic variables: gender, age, self-reported skin color, marital status, place of birth, religion, monthly per capita household income (calculated as a multiple of the minimum wage), number of residents at home, number of appliances in the home and coverage of private health insurance;

- Health behavior: physical activity during leisure time: those who performed no physical activity at all were considered sedentary; smoking habits: smoker (yes, no); alcohol risk use (positive, negative) assessed by the Alcohol Use Disorders Identification Test (AUDIT), with 8 or more points being considered positive 18; alcohol intake (drinkers, non-drinkers); daily intake (yes, no) of fruit, vegetables, legumes, soft drinks and milk; engaged in diet for losing weight (yes, no).

- $\quad$ Body mass index $\left(\mathrm{BMI}=\mathrm{kg} / \mathrm{m}^{2}\right)$, calculated from reported information on weight and height data, using the categories established for the elderly: $<22 \mathrm{~kg} / \mathrm{m}^{2}$ (underweight); between 22 and $27 \mathrm{~kg} / \mathrm{m}^{2}$ (eutrophics); and $>27 \mathrm{~kg} / \mathrm{m}^{2}$ (over- 
weight) ${ }^{19}$. The variable analyzed was overweight (yes, no).

- Health status (conditions listed on checklist) (yes, no): arterial hypertension, diabetes mellitus, cancer, rheumatism/arthritis, osteoporosis, asthma, bronchitis, emphysema, tendonitis, vascular disease, symptoms (headache, back pain, allergy, dizziness/vertigo, insomnia); number of chronic diseases reported: two or more; minor mental disorders (yes, no), assessed using the Self-Reporting Questionnaire (SRQ-20), with a $7 / 8$ cutoff point 20 ; poor or very poor self-rated health (yes, no); and visual impairment (yes, no). - Use of health services (yes, no): use of services in previous two weeks; hospitalization and surgery in previous 12 months; visit to dentist in the last year; use of medicines in previous three days; use of glasses/lenses; and use of dentures. For individuals with hypertension and diabetes, the following variables were analyzed: regular visits to the doctor to monitor the disease; orientations received on how to cope with the disease; time elapsed since last appointment and actions taken to control the disease.

In this study the dependents variables were all the health status and health services use indicators. The independent variable was educational level (years of schooling) and age and sex were used to produce adjusted prevalence ratios. The other demographic and socioeconomic variables were used to describe the social characteristics of the elderly groups defined by schooling level. Prevalence ratios of health services use, hospitalization, surgery and medicine intake were also adjusted for the number of chronic disease.

The association between variables was determined using the chi-square test, with a $5 \%$ level of significance. Simple and multiple Poisson regression models with robust variance were used to estimate crude and adjusted prevalence ratios and respective 95\%CI. The different weights of the sampled individuals and the effect of the sample design were taken into account in the analyses, using the Stata 11.0 software (Stata Corp., College Station, USA). The study received approval from the Ethics Research Committee of the Medical Science Faculty (Faculdade de Ciências Médicas) of the Campinas State University (Universidade Estadual de Campinas UNICAMP - process n. 079/2007).

\section{Results}

Among the sampled individuals, there was a $6.5 \%$ loss due to refusal of the resident to allow the pre-survey of the individuals of the selected household. Among the 1,558 elderly individu- als identified in the pre-survey, $2.3 \%$ refused to participate in the study. Thus, the data on 1,518 individuals aged 60 years of more were analyzed, with valid information on schooling, age and gender; $57.2 \%$ were female and $54 \%$ were between 60 and 69 years of age. There were statistically significant differences $(p<0.001)$ for all social and demographic indicators analyzed between the elderly from different educational levels (Table 1). Among the segment with the highest degree of schooling, there was a greater proportion of people who had white skin color, were married, born in Campinas or another city in the São Paulo State, Catholic, had a higher per capita household income, a lower number of residents in the household, a greater number of appliances in the household, and had private health insurance.

Regarding health behavior (Table 2), the segment with the highest degree of schooling had greater proportions of elderly individuals who are alcoholic drinkers and who are physically active in their leisure time. Prevalence ratios (adjusted for age and gender) regarding daily intake of fruit, legumes and vegetables and dieting were significantly higher among the elderly individuals with the highest educational levels. Moreover, a significantly lower proportion of the individuals in this stratum were overweight. The segment with four to eight years of schooling had a significantly higher proportion of individuals who consume alcoholic beverages, and who eat fruits and vegetables every day, in comparison to the segment with the lowest degree of schooling.

The elderly individuals with the highest degree of schooling had a lower prevalence of hypertension, diabetes, headaches, back pain, dizziness/vertigo, poor/very poor self-rated health and visual impairment (Table 3). However, there was a higher prevalence of tendonitis/repetitive strain injury in this stratum. No associations were found between schooling and the others diseases and health problems analyzed.

The prevalence of dental appointments in the previous year was significantly higher among the elderly individuals with the highest degree of schooling. However, there were no differences between this stratum and the group with lower educational levels in the use of health services in the previous two weeks, hospitalizations and surgeries in the previous year and medicine intake in the previous three days. The segment with the highest education level also had a greater proportion of people who used glasses or contact lenses and a lesser use of dentures (Table 3).

Statistically significant differences were found between the middle (four to eight years) and lowest (three years or less) schooling strata in the 
Demographic and socioeconomic characteristics according to the level of education in an elderly population. Campinas, São Paulo State, Brazil, 2008/2009.

\begin{tabular}{|c|c|c|c|c|c|c|}
\hline \multirow[t]{2}{*}{ Variables } & \multirow[t]{2}{*}{$\mathrm{n}$} & \multicolumn{3}{|c|}{ Educational level (in years) } & \multirow[t]{2}{*}{ p-value } & \multirow[t]{2}{*}{ Total } \\
\hline & & $0-3[n=546]$ & $4-8[n=612]$ & $9+[n=360]$ & & \\
\hline Sex & & & & & $<0.001$ & \\
\hline Male & 615 & 35.5 & 42.2 & 53.9 & & 42.8 \\
\hline Female & 903 & 64.5 & 57.8 & 46.1 & & 57.2 \\
\hline Age group & & & & & $<0.001$ & \\
\hline $60-69$ & 819 & 43.7 & 56.9 & 63.5 & & 53.9 \\
\hline $70-79$ & 499 & 38.3 & 30.3 & 29.2 & & 32.8 \\
\hline $80+$ & 200 & 18.0 & 12.8 & 7.3 & & 13.3 \\
\hline Skin color & & & & & $<0.001$ & \\
\hline White & 1,157 & 67.8 & 77.4 & 87.9 & & 76.7 \\
\hline Black/Mixed/Other & 359 & 32.2 & 22.6 & 12.1 & & 23.3 \\
\hline Marital status & & & & & $<0.001$ & \\
\hline Married/Cohabitating & 846 & 50.1 & 56.8 & 65.2 & & 56.6 \\
\hline Single & 100 & 5.9 & 5.9 & 8.7 & & 6.6 \\
\hline Divorced/Widow & 572 & 44.0 & 37.3 & 26.1 & & 36.8 \\
\hline Place of birth & & & & & $<0.001$ & \\
\hline Campinas & 311 & 10.1 & 25.4 & 28.0 & & 20.7 \\
\hline Other city of São Paulo State & 699 & 43.1 & 49.3 & 45.6 & & 46.2 \\
\hline Other State & 506 & 46.8 & 25.3 & 26.4 & & 33.1 \\
\hline Religion & & & & & $<0.001$ & \\
\hline Catholic & 1,008 & 67.0 & 65.5 & 67.7 & & 66.6 \\
\hline Evangelical & 335 & 27.8 & 22.5 & 11.5 & & 21.6 \\
\hline Others/None & 174 & 5.2 & 12.0 & 20.8 & & 11.8 \\
\hline Number of residents & & & & & $<0.001$ & \\
\hline $1-2$ & 827 & 47.0 & 55.2 & 64.7 & & 54.7 \\
\hline $3-4$ & 478 & 33.3 & 32.5 & 27.8 & & 31.6 \\
\hline 5 or + & 213 & 19.7 & 12.3 & 7.5 & & 13.7 \\
\hline Per capita income (minimum wage) & & & & & $<0.001$ & \\
\hline$<1$ & 607 & 55.8 & 34.3 & 24.0 & & 39.2 \\
\hline $1-4$ & 738 & 41.7 & 58.6 & 42.1 & & 48.5 \\
\hline$>4$ & 173 & 2.5 & 7.1 & 33.9 & & 12.3 \\
\hline Household appliances & & & & & $<0.001$ & \\
\hline $0-4$ & 190 & 20.2 & 11.3 & 2.1 & & 12.1 \\
\hline $5-9$ & 626 & 50.8 & 44.3 & 20.0 & & 40.4 \\
\hline 10 or + & 702 & 29.0 & 44.4 & 77.9 & & 47.5 \\
\hline Health insurance & & & & & $<0.001$ & \\
\hline Yes & 714 & 31.6 & 46.1 & 74.0 & & 48.1 \\
\hline No & 801 & 68.4 & 53.9 & 26.0 & & 51.9 \\
\hline
\end{tabular}

frequency of headaches, back pain, in the selfassessment of health, use of health services in the previous two weeks, dental appointments in the previous year and the use of glasses (Table 3 ).

In the analysis of the use of health services and disease control practices among the elderly individuals who reported having hypertension $(n=818)$ or diabetes $(n=332)$, there were no sta- tistically significant differences between strata with regard to regular visits to the doctor, receiving medical orientations and the regular use of medications. Statistically significant differences between educational strata were found for the practice of physical activity to control hypertension and the adoption of a restricted diet to control diabetes (Table 4). 
Prevalence (\%) and adjusted * prevalence ratios (PR) of health behavior according to educational level in an elderly population. Campinas, São Paulo State, Brazil, 2008/2009.

\begin{tabular}{|c|c|c|c|c|c|c|}
\hline \multirow[t]{2}{*}{ Variables } & \multicolumn{3}{|c|}{ Schooling (in years) } & \multirow[t]{2}{*}{$\mathrm{p}$-value ** } & \multirow{2}{*}{$\begin{array}{c}\text { Adjusted PR } \\
(2) /(1)\end{array}$} & \multirow{2}{*}{$\begin{array}{l}\text { Adjusted PR } \\
\text { (3)/(1) }\end{array}$} \\
\hline & $0-3(1)[n=546]$ & $4-8(2)[n=612]$ & $9+(3)[n=360]$ & & & \\
\hline Smokers & 11.1 & 12.1 & 10.7 & 0.7766 & $1.00(0.96-1.03)$ & $0.97(0.93-1.01)$ \\
\hline Alcohol drinkers & 20.6 & 30.2 & 46.9 & $<0.001$ & $1.37(1.07-1.75)$ & $1.94(1.51-2.51)$ \\
\hline AUDIT (Positive) & 3.7 & 4.1 & 4.9 & 0.6890 & $0.86(0.36-2.05)$ & $0.80(0.30-2.12)$ \\
\hline Sedentary in leisure time & 76.4 & 69.3 & 53.5 & $<0.001$ & $0.92(0.85-0.99)$ & $0.72(0.62-0.83)$ \\
\hline Diet for losing weight & 26.9 & 34.6 & 45.8 & 0.0146 & $1.22(0.82-1.82)$ & $1.60(1.08-2.38)$ \\
\hline $\mathrm{BMI}>27 \mathrm{~kg} / \mathrm{m}^{2}$ & 42.6 & 37.9 & 32.5 & 0.0260 & $0.97(0.92-1.01)$ & $0.93(0.88-0.99)$ \\
\hline \multicolumn{7}{|l|}{ Daily consumption of } \\
\hline Fruits & 46.6 & 59.4 & 72.4 & $<0.001$ & $1.32(1.12-1.56)$ & $1.68(1.38-2.03)$ \\
\hline Legumes & 38.1 & 43.3 & 56.3 & 0.0024 & $1.18(0.97-1.45)$ & $1.64(1.23-2.18)$ \\
\hline Vegetables & 44.7 & 55.2 & 69.2 & $<0.001$ & $1.26(1.05-1.51)$ & $1.63(1.33-2.01)$ \\
\hline Soft drinks & 11.8 & 9.6 & 13.8 & 0.1679 & $0.78(0.52-1.15)$ & $1.05(0.69-1.59)$ \\
\hline Milk & 67.0 & 68.3 & 63.8 & 0.5299 & $1.05(0.94-1.18)$ & $1.02(0.89-1.17)$ \\
\hline
\end{tabular}

BMI: body mass index.

* Adjusted by sex and age;

** Chi-square test.

\section{Discussion}

The most important finding of this study was to verify that the strong social inequalities in this elderly population were associated to different illness and health-related behavior profiles, but the association of schooling with indicators of health services use was much more attenuated.

The strong correlation between degree of schooling and socio-demographic indicators is consistent with what has been reported elsewhere in the literature. Schooling is one of the most often used indicators for the analysis of social inequalities in health $1,7,21$. It is an indicator which remains stable during the life course and has higher validity and is easier to obtain than others socioeconomic variables, like income for example. However, schooling is closely related to age, as older generations in Brazil had fewer opportunities of access to the educational system than younger ones. Nowadays, most of the Brazilian elderly nowadays have a lower level of education than younger generations. Nonetheless, the results of the present study reveal that, even among the elderly, schooling is an adequate variable to identify social groups with very different patterns of living conditions.

A greater proportion of individuals from the higher educational level consume alcoholic beverages compared to those from the lower stratum, but with no greater prevalence of risky drinking, as there was no association between schooling and AUDIT results. A household survey carried out in capital cities in Brazil 22 also found a greater prevalence of alcohol intake among the segment with the highest schooling level. As in the present study, the Risk and Protective Factors Surveillance System for Chronic Non-Communicable Diseases Through Telephone Interview (VIGITEL) found no significant differences regarding alcohol abuse between social strata 23 . The data in the literature on the association between alcohol intake, alcohol abuse and social strata are contradictory, but most of the publications reported greater frequency of alcohol intake among individuals of a higher socioeconomic level and greater alcohol dependence/risk drinking among lower strata 24,25,26.

The elderly with a greater degree of schooling were significantly more physically active in leisure time than those from lower levels, which is similar to findings reported in previous studies 26,27. Data from VIGITEL 2007 analyzing the residents of capital cities in Brazil also reveal a significantly higher prevalence of physical activity in the higher educational stratum 23 . A study carried out among elderly individuals in England reported a greater prevalence of smokers, alcohol abuse and sedentary lifestyle in groups with a poorer socioeconomic status 26 . In the present study, there was no association between education and smoking habits, which is similar to the 
Prevalence (\%) and prevalence ratios (PR) * of chronic conditions and use of health services according to educational level among the elderly. Campinas, São Paulo State, Brazil, 2008/2009.

\begin{tabular}{|c|c|c|c|c|c|c|}
\hline \multirow[t]{3}{*}{ Variables } & \multicolumn{3}{|c|}{ Schooling (in years) } & \multirow[t]{3}{*}{$\mathrm{p}$-value ** } & \multirow[t]{3}{*}{ Adjusted PR (2)/(1) } & \multirow[t]{3}{*}{ Adjusted PR (3)/(1) } \\
\hline & $0-3(1)$ & $4-8(2)$ & $9+(3)$ & & & \\
\hline & {$[n=546]$} & {$[\mathrm{n}=612]$} & {$[n=360]$} & & & \\
\hline Hypertension & 59.3 & 53.7 & 44.0 & $<0.001$ & $0.94(0.85-1.04)$ & $0.80(0.69-0.92)$ \\
\hline Diabetes & 23.8 & 23.2 & 16.3 & 0.0102 & $1.00(0.82-1.22)$ & $0.71(0.54-0.95)$ \\
\hline Cancer & 5.5 & 4.7 & 6.5 & 0.5261 & $0.88(0.51-1.49)$ & $1.19(0.58-2.45)$ \\
\hline Rheumatism/Arthritis/Arthrosis & 27.8 & 26.9 & 22.3 & 0.1195 & $1.03(0.85-1.25)$ & $0.94(0.75-1.17)$ \\
\hline Osteoporosis & 18.5 & 15.0 & 10.1 & 0.0088 & $0.94(0.69-1.27)$ & $0.76(0.49-1.18)$ \\
\hline Asthma/Bronchitis/Emphysema & 7.9 & 5.6 & 4.0 & 0.0631 & $0.77(0.49-1.20)$ & $0.58(0.28-1.20)$ \\
\hline Tendonitis/Repetitive strain injury & 3.3 & 5.0 & 7.2 & 0.0561 & $1.50(0.76-2.98)$ & $2.34(1.15-4.79)$ \\
\hline Headache/Migraines & 23.6 & 18.2 & 12.4 & $<0.001$ & $0.75(0.60-0.94)$ & $0.52(0.36-0.75)$ \\
\hline Back pain & 49.7 & 42.3 & 37.0 & 0.0020 & $0.86(0.75-0.99)$ & $0.77(0.64-0.92)$ \\
\hline Allergy & 19.8 & 20.6 & 23.4 & 0.4285 & $1.07(0.84-1.37)$ & $1.29(0.95-1.73)$ \\
\hline Dizziness/Vertigo & 22.8 & 19.0 & 14.4 & 0.0124 & $0.86(0.69-1.07)$ & $0.67(0.47-0.97)$ \\
\hline Insomnia & 24.3 & 23.1 & 19.1 & 0.0880 & $0.99(0.83-1.20)$ & $0.88(0.69-1.14)$ \\
\hline Minor mental disorders (SRQ-20) & 19.0 & 15.6 & 10.8 & 0.0155 & $0.91(0.66-1.26)$ & $0.71(0.48-1.06)$ \\
\hline Prevalence of 2 or more chronic diseases & 63.6 & 55.9 & 47.9 & 0.0005 & $0.93(0.83-1.04)$ & $0.84(0.73-0.96)$ \\
\hline Poor/very poor self-rated health & 17.4 & 10.8 & 6.9 & $<0.001$ & $0.94(0.91-0.98)$ & $0.91(0.88-0.94)$ \\
\hline Visual impairment & 28.5 & 23.0 & 15.7 & 0.0225 & $0.83(0.62-1.12)$ & $0.57(0.33-0.99)$ \\
\hline Health service use (last 2 weeks) & 21.8 & 29.7 & 23.2 & 0.0069 & $1.40(1.13-1.73) * \star \star$ & $1.14(0.85-1.58) * \star *$ \\
\hline Hospitalization (last year) & 14.1 & 15.3 & 13.1 & 0.6365 & $1.16(0.85-1.58) * \star \star$ & $1.08(0.76-1.53)$ *** \\
\hline Surgery (last year) & 10.1 & 10.6 & 11.8 & 0.8028 & $0.99(0.97-1.02) * \star \star$ & 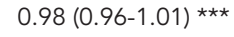 \\
\hline Dentist visit (last year) & 17.6 & 33.8 & 62.7 & $<0.001$ & $1.84(1.43-2.36)$ & $3.37(2.60-4.36)$ \\
\hline Medicines (last 3 days) & 82.1 & 79.6 & 79.4 & 0.5985 & $1.01(0.98-1.03)^{\star \star \star}$ & $1.03(1.00-1.06) * * *$ \\
\hline Wearing glasses or contact lenses & 67.0 & 83.7 & 87.9 & $<0.001$ & $1.25(1.15-1.35)$ & $1.32(1.21-1.44)$ \\
\hline Wearing dental prosthesis & 76.2 & 71.1 & 48.3 & $<0.001$ & $0.97(0.89-1.05)$ & $0.68(0.59-0.78)$ \\
\hline
\end{tabular}

SRQ-20: Self-Reporting Questionnaire.

*Adjusted by sex and age;

** Chi-square test;

*** Adjusted by age, sex and number of chronic diseases.

finding on elderly reported by Azevedo-e-Silva et al. 28 based on the data from VIGITEL 2006, but it is different from results reported by other authors 26,29 .

Healthy behavior, such as dieting and careful nutrition, as expressed by the greater intake of fruit, vegetables and legumes, has also been reported as being higher among segments with a greater degree of schooling ${ }^{30,31}$, as found in the present study.

Social inequalities in healthy behavior have a strong influence on the maintenance or on broadening the social disparities regarding disease and mortality rates. Health-related behavior is an important mediator of the effect of social inequality on health. A study carried out in England reports that approximately $72 \%$ of the difference in mortality rates between social classes stems from behavioral differences, with diet accounting for $17 \%$, a lack of physical activity accounting for $21 \%$, at-risk alcohol intake accounting for $12 \%$ and cigarettes - the most important risk factor for chronic diseases - accounting for $35 \%$ of the increase in the risk of death among socially underprivileged segments ${ }^{32}$. It is recognized that encouraging the practice of physical activities, better dietary habits, the moderate use of alcoholic beverages and quitting smoking is an important strategy for health promotion and the prevention and control of diseases as well as promoting a better quality of life. The incisive action of the public sector in the implementation of policies that encourage healthy behavior is fundamental to the promotion of equity in health.

Social disparities in the prevalence of chronic disease have been consistently reported in other 
Practices to control disease among hypertensive and diabetic individuals by educational level. Campinas, São Paulo State, Brazil, 2008/2009.

\begin{tabular}{|c|c|c|c|c|}
\hline \multirow[t]{2}{*}{ Diseases and control practices } & \multicolumn{3}{|c|}{ Educational level (in years) } & \multirow[t]{2}{*}{$p$-value * } \\
\hline & $0-3(\%)$ & $4-8(\%)$ & $9+(\%)$ & \\
\hline Hypertension & {$[n=326]$} & {$[n=332]$} & {$[n=159]$} & \\
\hline Do you regularly visit the doctor? & 86.9 & 86.3 & 86.0 & 0.9557 \\
\hline Received medical orientation? & 89.4 & 83.7 & 82.4 & 0.0726 \\
\hline When was your last visit? & & & & 0.8687 \\
\hline Last month & 30.4 & 29.6 & 26.8 & \\
\hline 1 to 6 months ago & 54.5 & 54.6 & 53.6 & \\
\hline 6 months or more & 15.1 & 15.8 & 19.5 & \\
\hline \multicolumn{5}{|l|}{ What do you do to control the disease? } \\
\hline Diet without salt & 26.3 & 30.7 & 24.3 & 0.3702 \\
\hline Diet restriction for losing weight & 3.3 & 4.2 & 5.0 & 0.5952 \\
\hline Physical activity & 6.0 & 5.9 & 18.6 & $<0.001$ \\
\hline Regular use of medicines & 92.9 & 93.7 & 91.8 & 0.7201 \\
\hline Diabetes & {$[n=131]$} & {$[n=143]$} & {$[n=58]$} & \\
\hline Do you regularly visit the doctor? & 92.5 & 87.4 & 93.3 & 0.1887 \\
\hline Received medical orientation? & 92.5 & 90.2 & 94.7 & 0.5719 \\
\hline When was your last visit? & & & & 0.9930 \\
\hline Last month & 38.3 & 39.0 & 38.9 & \\
\hline More than 1 month ago & 61.7 & 61.0 & 61.1 & \\
\hline \multicolumn{5}{|l|}{ What do you do to control the disease? } \\
\hline Diet & 24.1 & 48.5 & 51.6 & 0.0029 \\
\hline Diet restriction for losing weight & 2.2 & 6.6 & 5.1 & 0.2631 \\
\hline Physical activity & 9.3 & 9.5 & 17.9 & 0.1572 \\
\hline Regular use of insulin & 25.1 & 22.9 & 18.9 & 0.6308 \\
\hline Regular use of oral medicines & 69.9 & 65.4 & 63.6 & 0.6701 \\
\hline
\end{tabular}

* Chi-square test.

countries as well as in Brazilian studies. Many chronic diseases have a social gradient, with a greater prevalence among more socially vulnerable segments, as seen in the present study with regard to hypertension, diabetes, headaches, back pain and dizziness/vertigo. The Brazilian $\mathrm{Na}$ tional Household Sampling Survey 2003 (PNAD) also reports that all the chronic conditions included in the survey were more prevalent among the population with the lowest degree of schooling, with the exception of tendonitis/synovitis 33 . Machado et al. 34 reported that chronic musculoskeletal symptoms are less prevalent among individuals with a greater degree of schooling, whereas no statistically significant association was found between rheumatism and schooling, which is similar to the finding reported in the present study. The presence of two or more health conditions was less frequent among the stratum that had studied nine or more years, which is similar to the finding reported by other authors 35 .

Social gradients in the prevalence of chronic conditions are also reported for other countries $1,10,36$. A study carried out in the USA reports that segments with less schooling have a greater prevalence of hypertension, chronic bronchitis, cancer, diabetes, back pain and symptoms of mental illness, while no such pattern was found for asthma or arthritis 36 . Although unfavorable gradients in illness among the population with the lowest socioeconomic status are widely reported, studies have addressed the possibility of reducing or even eliminating these differences, through appropriate actions involving public policies and health care systems 15 .

There are few diseases with inverse gradients affecting more economically privileged segments, as observed in the present study for tendonitis, similar to the results of others studies 33,37 . 
Social inequalities are also evident in the frequency of visual impairment among the elderly analyzed. In the USA, data from the National Health Interview Survey indicate that the largest percentage of those with visual impairment (14\%) is in the lowest educational stratum, whereas the segment with the highest degree of schooling has a prevalence of $7 \% 38$. A study developed in four regions of the State of São Paulo, detected a greater prevalence of visual impairment among individuals from households with heads in the lowest degree of schooling 39 . We observed that the use of glasses and contact lenses was more frequent in the stratum with higher education, which partially accounts for the lower frequency of complaints of visual impairment in this social segment.

Poor self-rated health was more frequent among elderly people with a lower degree of schooling. Previous studies have also reported intense social inequalities with regard to self-rated health 10,40 . Self-rated health has been identified as being strongly associated with functional disability among elderly individuals in Brazil 41 .

Social inequalities on health status and on illness prevalence tend to be less accentuated among elderly individuals than among the young due to the preventable and premature deaths that particularly affect the economically underprivileged segments of society 12 .

To assess inequalities in the use of basic health services, it is necessary to have data from population-based studies that help to identify possible situations of exclusion and barriers of access. Despite considerable differences in living conditions and health indicators among the elderly from different social strata, less important inequalities were found regarding the use of health services. No significant differences were found regarding hospitalizations and surgeries in the previous year and the use of medicines in the previous three days. Also, there was no difference between the two extreme strata related to the use of health services in the last two weeks. The analyses regarding the use of health services among individuals with diabetes and hypertension reinforce this observation. There were, among them, no significant differences between the different schooling strata in the use of routine medical visits, the regular use of medications or the receiving of medical orientations. These findings indicate a possible reduction in inequity regarding access to medical care through the actions of the Brazilian public health care system. The city where the survey was developed has a reasonably organized network of public services capable of meeting the basic health needs of the population dependent on public health care. A total of $52.3 \%$ (95\%CI: 44.2-60.2) of the elderly individuals in the city do not have private health insurance and therefore depend exclusively on the public health care system. A total of $68.7 \%$ of the elderly individuals in the lower educational level and even $26.1 \%$ of those in the segment with the highest degree of schooling are dependent on the public system (Table 1).

Inequity remains evident in access to oral health care, which is similar to findings reported in previous studies carried out in Brazil 42 as well as in other countries 43 . In a national evaluation, Barros et al. 42 found greater inequalities in oral health care in children and in the elderly. The use of dentures was reported more by individuals with fewer years of schooling, which likely stems from the lesser access to dental services throughout life among the low-income population.

Important inequalities were also found in individuals with hypertension and diabetes, on non-medicinal practices for controlling disease, such as physical activity and a controlled diet. A previous study found similar results 44 . Then, greater development and consolidation of the interventions of public health care services in non-medicinal practices for the control of disease are fundamental to ensuring advances in health equity.

The present study has limitations that should be addressed. One is the fact that the data on illness, health behavior and the use of health services consisted of self-reported information. Data on socially undesirable behavior are prone to be underestimated. The same occurs with the estimates for obesity based on the BMI, calculated from self-reported weight and height, which tend to be underestimated, especially among elderly individuals 45 . Some authors argue for the use of self-reported information regarding chronic diseases. Validation studies comparing this information to medical records and patient charts have revealed different degrees of accuracy depending on the type of disease, the presence of co-morbidities and the socio-demographic characteristics of the respondent 46 . An individual's recognition of the disease depends on his/her perception of signs and symptoms, the access to medical services and diagnostic tests, the quality of orientation given by health care professionals and the understanding of the information received. Important differences in estimates of disease prevalence occur depending on the method employed. The use of a checklist, as applied in the present study, enhances the validity of the information obtained in surveys 47 .

Another limitation of the present study resides in the cross-sectional design, which does not allow for inferences regarding causality, meaning 
that it is therefore not possible to discern the direction of the effect. Moreover, sample size, even when adequate for estimating overall prevalence, becomes insufficient for detecting associations in some analyses. It is also necessary to consider the existence of type 2 errors on the various associations that were tested.

The magnitude of the differences encountered in the prevalence of disease between socioeconomic strata also tends to be underestimated by the lesser access to medical and diagnostic services among segments with lower degrees of schooling, leading a greater proportion of these individuals to be unaware of the fact that they have certain diseases. The estimated social disparities in the prevalence of disease may therefore actually be lower than the actual situation 48 . In spite of this, the illness indices have often proven to be higher in individuals from lower socioeconomic strata 33,36 , as seen in this study.

The present study assessed physical activity only in the leisure context considering this to be a more adequate indicator of a healthier lifestyle.
Another care taken in this study was the use of BMI categories recommended for elderly individuals, with cutoff points that take into account the changes in body composition stemming from the ageing process 19 .

\section{Conclusion}

The prevalent social inequalities regarding living conditions and health-related behavior imply the maintenance or even future broadening of health inequalities. The findings of the present study point to the urgent need for broader-scoped social and inter-sector policies directed at improving education opportunities and the distribution of income as well as the consolidation of health service strategies for the promotion of healthier lifestyles 26 . The offering of health services with good coverage and quality by the Brazilian public health care system may effectively remedy social inequality regarding the risk of becoming ill and dying.

\section{Resumo}

O objetivo do estudo foi avaliar desigualdades sociais no estado de saúde, comportamentos de saúde e uso de serviços segundo o nível de escolaridade. É um estudo transversal de base populacional com 1.518 idosos residentes em Campinas, São Paulo, Brasil (ISA-Camp 2008/2009). Observaram-se significativas diferenças sociodemográficas entre os estratos estudados. Idosos de melhor nível educacional, em maior proporção, consomem bebidas alcoólicas, são mais ativos fisicamente em contexto de lazer e têm padrões de dieta mais saudáveis. Apresentam, também, menor prevalência de hipertensão, diabetes, tontura, dor de cabeça, dor nas costas, deficiência visual, uso de prótese dentária e de saúde autoavaliada como ruim. Mas, não houve diferença no uso de serviços de saúde, hospitalizações, cirurgias e uso de medicamentos. Entre os hipertensos ou diabéticos, não houve diferença quanto ao uso regular de serviços de saúde e de medicamentos. Os resultados apontam a presença de desigualdades sociais em diversos indicadores de saúde e a presença de equidade no acesso a alguns componentes dos serviços de saúde.

Saúde do Idoso; Inquéritos de Morbidade; Iniquidade Social; Prevalência

\section{Contributors}

M. B. A. Barros was responsible for the conception and drafting of the article and planned and executed the statistical analyses. P. M. S. B. Francisco executed the statistical analyses and collaborated on the discussion and drafting of the manuscript. M. G. Lima and C. L. G. Cesar collaborated in the discussion and drafting of the manuscript.

\section{Acknowledgments}

The authors are grateful to the CNPq (process $\mathrm{n}^{\circ}$. 409747/2006-8) for financing the research and for providing productivity scholarships to $\mathrm{M}$. B. A. Barros and C. L. G. Cesar; to the Brazilian Ministry of Health and the Campinas Health Department for financial support to carry out the survey (Partnership UNICAMP/Funcamp/ SMS no. 4300); to FAPESP for a post-doctoral scholarship awarded to P. M. S. B. Francisco. 


\section{References}

1. Braveman PA, Cubbin C, Egerter S, Williams DR, Pamuk E. Socioeconomic disparities in health in the United States: what the patterns tell us. Am J Public Health 2010; 100 Suppl 1:S186-96.

2. Silva JB, Barros MBA. Epidemiologia e desigualdade: notas sobre a teoria e a história. Rev Panam Salud Pública 2002; 12:375-83.

3. World Health Organization. Equitity in health and health care: a WHO/SIDA initiative. Geneva: World Health Organization; 1996.

4. Comissão Nacional dos Determinantes Sociais em Saúde. As causas sociais das iniqüidades em saúde no Brasil/CNDSS. Rio de Janeiro: Editora Fiocruz; 2008.

5. Marmot M. WHO Commission on Social Determinants of Health. Closing the health gap in a generation: the work of the Commission on Social Determinants of Health and its recommendations. Glob Health Promot 2009; Suppl 1:23-7.

6. Gwatkin DR. Health inequalities and the health of the poor: What can we do? Bull World Health Organ 2000; 78:3-18.

7. Liberatos P, Link BG, Kelsey JL. The measurement of social class in epidemiology. Epidemiol Rev 1988; 10:87-120.

8. Muntaner C, Borrel C, Benach J Pasarín MI, Ferandes $\mathrm{E}$. The association of social class and social stratification with patterns of general and mental health in a Spanish population. Int J Epidemiol 2003; 32:950-8.

9. Wilkinson RG. Income distribution and life expectancy. BMJ 1992; 304:165-8.

10. Espelt A, Borrell C, Rodríguez-Sanz M, Muntaner C, Pasarín MI, Benach J, et al. Inequalities in health by social class dimensions in European countries of different political traditions. Int J Epidemiol 2008; 37:1095-105.

11. Robert S, House J. SES differentials in health by age and alternative indicators of SES. J Aging Health 1996; 8:359-88.

12. Crimmins EM, Kim JK, Seeman TE. Poverty and biological risk: the earlier "aging" of the poor. J Gerontol A Biol Sci Med Sci 2009; 64:286-92.

13. Adams JM, White M. biological ageing: a fundamental, biological link between socioeconomic status and health? Eur J Public Health 2004; 14:331-4.

14. Huisman M, Kunst AE, Mackenbach JP. Socioeconomic inequalities in morbidity among the elderly: a European overview. Soc Sci Med 2003; 57:861-73.

15. Kaplan MS, Huguet N, Feeny DH, McFarland BH. Self-reported hypertension prevalence and income among older adults in Canada and the United States. Soc Sci Med 2010; 70:844-9.

16. Fang R, Kmetic A, Millar J, Drasic L. Disparities in chronic disease among Canada's low-income populations. Prev Chronic Dis 2009; 6:A115.

17. Barros MBA, César CLG, Carandina L, Goldbaum M. As dimensões da saúde: Inquérito populacional em Campinas, SP. São Paulo: Editora Hucitec; 2008.
18. Barbor TE, La Fuente JR, Saunders J, Grant M. AUDIT - The alcohol use disorders identification test: guidelines for use in primary health care. Geneva: World Health Organization; 1992.

19. Cervi A, Franceschni SCC, Priore SE. Análise crítica do uso do índice de massa corporal para idosos. Rev Nutr 2005; 18:765-75.

20. Mari JJ, Williams P. A validity study of a psychiatric screening questionnaire (SRQ-20) in primary care in the city of Sao Paulo. Br J Psychiatry 1986; 148:23-6.

21. Mackenbach JP, Stirbu I, Roskam AJ, Schaap MM, Menvielle G, Leinsalu M, et al. Socioeconomic inequalities in health in 22 European countries. N Engl J Med 2008; 358:2468-81.

22. Instituto Nacional de Câncer. Inquérito domiciliar sobre comportamentos de risco e morbidade referida de doenças e agravos não transmissíveis: Brasil, 15 capitais e Distrito Federal, 2002-2003. Rio de Janeiro: Instituto Nacional de Câncer; 2004.

23. Secretaria de Vigilância em Saúde/Secretaria de Gestão Estratégica e Participativa. VIGITEL Brasil 2007: vigilância de fatores de risco e proteção para doenças crônicas por inquérito telefônico. Brasília: Ministério da Saúde; 2008. (Série G. Estatísticas e Informação em Saúde).

24. Mendoza-Sassi RA, Beria JU. Prevalence of alcohol use disorders and associated factors: a populationbased study using AUDIT in southern Brazil. Addiction 2003; 98:799-804.

25. Barros MBA, Botega N, Dalgalarrondo P, Marin-Leon L, Oliveira HB. Prevalence of alcohol abuse and associated factors in a population-based study. Rev Saúde Pública 2007; 41:502-9.

26. Shankar A, McMunn A, Steptoe A. Health-related behaviors in older adults relationships with socioeconomic status. Am J Prev Med 2010; 38:39-46.

27. Florindo AA, Hallal PC, Moura EC, Malta DC. Practice of physical activities and associated factors in adults, Brazil, 2006. Rev Saúde Pública 2009; 43 Suppl 2:S65-73.

28. Azevedo-e-Silva G, Valente JG, Almeida LM, Moura EC, Malta DC. Tobacco smoking and level of education in Brazil, 2006. Rev Saúde Pública 2009; 43 Suppl 2:S48-56.

29. Peixoto SV, Firmo JO, Lima-Costa MF. Factors associated to smoking habit among older adults (The Bambuí Health and Aging Study). Rev Saúde Pública $2005 ; 39: 746-53$.

30. Jaime PC, Figueiredo IC, Moura EC, Malta DC. Factors associated with fruit and vegetable consumption in Brazil, 2006. Rev Saúde Pública 2009; 43 Suppl 2:S57-64.

31. Salehi L, Eftekhar H, Mohammad K, Tavafian SS, Jazayery A, Montazeri A. Consumption of fruit and vegetables among elderly people: a cross sectional study from Iran. Nutr J 2010; 13:2.

32. Stringhini S, Sabia S, Shipley M, Brunner E, Nabi $\mathrm{H}$, Kivimaki M, et al. Association of socioeconomic position with health behaviors and mortality. JAMA 2010; 303:1159-66. 
33. Barros MBA, Cesar CLG, Carandina L, Torre GD. Desigualdades sociais na prevalência de doenças crônicas no Brasil, PNAD-2003. Ciênc Saúde Coletiva 2006; 11:911-26.

34. Machado GPM, Barreto SM, Passos VMA, LimaCosta MF. Projeto Bambuí: prevalência de sintomas articulares crônicos em idosos. Rev Assoc Med Bras 2004; 50:367-72.

35. Barreto SM, Figueiredo RC. Doença crônica, auto-avaliação de saúde e comportamento de risco: diferença de gênero. Rev Saúde Pública 2009; 43 Suppl 2:38-47.

36. Lethbridge-Cejku M, Schiller JS, Bernadel L. Summary health statistics for U.S. adults: National Health Interview Survey, 2002. Vital Health Stat 10 2004; (222):1-151.

37. Frazão P, Costa CM, Almeida MF. Risks associated with tendinitis: effects from demographic, socioeconomic, and psychological status among Brazilian workers. Am J Ind Med 2010; 53:72-9.

38. Ryskulova A, Turczyn K, Makuc DM, Cotch MF, Klein RJ, Janiszewski R. Self reported age-related eye diseases and visual impairment in the United States: results of the 2002 National Health Interview Survey. Am J Public Health 2008; 98:454-61.

39. Castro SS, César CL, Carandina L, Barros MBA, Alves MCGP, Goldbaum M. Deficiência visual, auditiva e física: prevalência e fatores associados em estudo de base populacional. Cad Saúde Pública 2008; 24:1773-82.

40. Barros MBA, Zanchetta LM, Moura EC, Malta DC. Auto-avaliação da saúde e fatores associados, Brasil, 2006. Rev Saúde Pública 2009; 43 Suppl 2:S27-37.

41. Alves LC, Leite ID, Machado CJ. Factors associated with functional disability of elderly in Brazil: a multilevel analysis. Rev Saúde Pública 2010; 44:468-78.

42. Barros AJD, Bertoldi, AD. Desigualdades na utilização e no acesso a serviços odontológicos: uma avaliação em nível nacional. Ciênc Saúde Coletiva 2002; 7:709-17.
43. Patel R, Lawlor DA, Ebrahim S; British Women's Heart and Health Study cohort. Socio-economic position and the use of preventive health care in older British women: a cross-sectional study using data from the British Women's Heart and Health Study cohort. Fam Pract 2007; 24:7-10.

44. Zaitune MPA, Barros MBA, Cesar CLG, Carandina L, Goldbaum M. Hipertensão em idosos: prevalência, fatores associados e práticas de controle no Município de Campinas, São Paulo, Brasil. Cad Saúde Pública 2006; 22:285-94.

45. Silveira EA, Araújo CL, Gigante DP, Barros AJD, Lima MS. Validação do peso e altura referidos para o diagnóstico do estado nutricional em uma população de adultos no Sul do Brasil. Cad Saúde Pública 2005; 21:235-45.

46. Skinner KM, Miller DR, Lincoln E, Lee A, Kazis LE. Concordance between respondent self-reports and medical records for chronic conditions: experience from the Veterans Health Study. J Ambul Care Manage 2005; 28:102-10.

47. Knight M, Stewart-Brown S, Fletcher L. Estimating health needs: the impact of a checklist of conditions and quality of life measurement on health information derived from community surveys. J Public Health Med 2001; 23:179-86.

48. Mackenbach JP, Looman CW, van der Meer JB. Differences in the misreporting of chronic conditions, by level of education: the effect on inequalities in prevalence rates. Am J Public Health 1996; 86:706-11.

Submitted on 16/Jun/2010

Final version resubmitted on 12/Nov/2010

Approved on 03/Jan/2011 